\title{
Isolation and characterization of a high-efficiency marine diesel oil-degrading bacterium
}

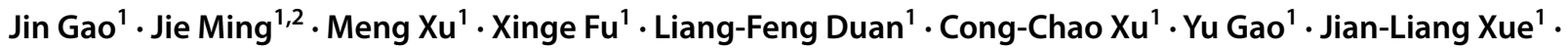 \\ Xin-Feng Xiao ${ }^{1}$
}

Received: 14 May 2020 / Accepted: 27 October 2020 / Published online: 5 January 2021

(C) The Author(s) 2021

\begin{abstract}
In the recent 50 years, marine oil spills had resulted in severe environmental pollution problems worldwide. In this study, 12 petroleum-degrading strains named MJ1 to MJ12, which can use diesel oil as the sole carbon source for growth, were isolated from the seawater in Jiaozhou Bay, China. Strain MJ4 has the highest diesel-degrading rate which is up to $26.54 \%$ in 5 days with the diesel oil concentration of $10 \mathrm{~g} / \mathrm{L}$. According to the BLAST research, 16SrRNA sequence of MJ4 showed 99\% similarity to Bacillus megaterium strain. Single-factor experiments and response surface methodology were carried out to optimize the environmental factors and their reciprocal action for affecting the diesel oil degradation process of Bacillus sp. MJ4. Results of single-factor experiments revealed that the highest degradation rate was obtained with temperature of $28^{\circ} \mathrm{C}, \mathrm{pH}$ of 8.8 , diesel oil concentration of $25 \mathrm{~g} / \mathrm{L}, P / N$ ratio of 0.56 , nitrogen and phosphorus dosage quantity of $0.35 \mathrm{~g} / \mathrm{L}$ and $0.18 \mathrm{~g} / \mathrm{L}$, respectively. A nonlinear regression equation of diesel oil degradation rate and $\mathrm{pH}$, temperature, $P / N$ ratio was obtained. The model predicted the maximum degradation rate of $72.21 \%$ with temperature of $28^{\circ} \mathrm{C}, \mathrm{pH}$ of $8.88, P / N$ ratio of 0.31 , respectively.
\end{abstract}

Keywords Bioremediation - Bacillus megaterium MJ4 - Environmental factors · Marine oil spill $\cdot$ Response surface methodology

\section{Introduction}

Nowadays, most of the industries and transport systems still depend on petroleum resource. In the process of oil exploitation and processing, a lot of wastewater and residues containing oil are produced, and crude oil spillages often occurs in the process of transportation. Oil spills had resulted in severe environmental pollution problems. Although annual statistics of oil spillages from 1970 to 2015 show a decline in the number and size due to the implementation of spill laws and conventions (Wu et al. 2019), the statistics show

Edited by Xiu-Qiu Peng

Yu Gao

gaoyu@ sdust.edu.cn

1 College of Safety and Environmental Engineering, Shandong University of Science and Technology, Qingdao 266590, China

2 College of Chemical Engineering, China University of Petroleum, Beijing 102249, China that 1.3 million tons of oil has been spilled into the ocean (Bao et al. 2012). Marine oil spill has a significant impact on the marine ecosystems and human health. Once oil spill happened, it could form into slick on the surface of the ocean. The slick blocks the change of $\mathrm{O}_{2} / \mathrm{CO}_{2}$, which leads to an oxygen depletion and destroys the balance of $\mathrm{CO}_{2}$ in ocean. Moreover, the slick blocks the sunshine and influences photosynthesis of the flora in the ocean. In addition, the oil in the ocean could harm human health by food chain. Diesel is a complex hydrocarbon distilled from crude oil with a carbon number between $\mathrm{C} 9$ and $\mathrm{C} 20$, such as paraffin, olefin, naphtha and aromatic compounds, which is mainly caused by accidental leakage of oil storage tank or oil pipeline (Adam and Duncan 1999; Mnif et al. 2015). Microbial communities responsible for the biogeochemical cycles are being truncated since diesel oil is toxic to general organisms (Kayode-Isola et al. 2008). The quantity and quality of oil mixtures and the properties of the affected ecosystems determine the durability of oil pollution (Xue et al. 2021). Conventional marine oil pollution remediation techniques include physical, chemical and thermal treatments which are 
costly and often cause secondary pollution. Bioremediation has been proved to be the most important eco-friendly and cost-effective technologies for the cleanup of petroleum pollutants (Atlas and Hazen 2011; Ron and Rosenberg 2014). Since many indigenous microorganisms have the ability to degrade petroleum, microbial technology is considered to be one of the important methods for the remediation of petroleum hydrocarbon pollution (Mahmoudi et al. 2013; Xu et al. 2020). Until now, more than 100 genera, 200 species of petroleum degradation microorganism have been discovered in marine environment, including 79 genera of bacteria, nine genera of cyanobacteria, 103 genera of fungi, and 19 genera of algae (Xue et al. 2015). However, since petroleum is mixture with different hydrocarbon structure, the effective bacteria for petroleum degradation are totally different (Rajasekar et al. 2007). According to the literature and the authors' results in research works, Pseudomonas (Richard and Vogel 1999), Corynebacterium (Rahman et al. 2002), Bacillus (Bento et al. 2005), Acinetobacter (Gallego et al. 2001), Enterobacter (Saadoun 2002) were isolated and identified as diesel degradation bacteria; all of them are able to degrade aliphatic hydrocarbon, cyclohexane, alkyl benzene and dicycloalkane. For marine diesel degradation, bacteria such as Arthrobacter, Rhodococcus (Michaud et al. 2004) have also been isolated and identified. Nevertheless, the marine petroleum degradation microorganisms are still scarce and the degradation efficiency is low. Thus, it is important to find the stable and efficient degrading bacteria and investigate the degrading character of the degrading bacteria. The degradation time of petroleum hydrocarbons in the environment is largely controlled by abiotic factors, such as the growth of microorganisms and the activity of enzymes that are related to petroleum hydrocarbon utilization. Because of the characters of ocean, environmental factors such as scarcity of necessary nutrients and low temperature limit the growth and degradation abilities of oil-degrading bacteria (Thavasi et al. 2011). Fertilizers containing bioavailable nitrogen and phosphorus have been successfully applied to enhance the biodegradation of petroleum on many different coastlines, including the arctic (Atlas and Bragg 2009; Swannell et al. 1999). However, dosage of nitrogen and phosphorus should be well investigated before application because they are the main element resulting in eutrophication of water body and structure change of marine ecosystem.

Response surface method (RSM) is a method used in mathematical statistics to analyze the relationship between multiple independent variables and one or more responses. It has been applied in many fields of science research, especially in the research to evaluate the interaction of several factors on microorganism activity in fermentation and degradation (Hallenbeck et al. 2015; Karpagam et al. 2015). Recently, RSM has been used in bioremediation of oil spills contamination (Huang et al. 2008; Pi et al. 2016).
Microbial degradation has been recognized as an efficient and environmentally friendly method in oil spill pollution remediation. However, efficient degradation strains are still lacking, and some environmental factors will greatly limit the petroleum hydrocarbon degradation performance of microbial strains. In addition, there has been an oil pipeline explosion near Jiaozhou Bay in which about 2000 tons crude oil spilled and most of them injected into Jiaozhou Bay. Considering above mentions, the purpose of this study is to obtain a high-efficiency oil-degrading bacteria. RSM was adopted to optimize the diesel degradation condition of the isolated strain to elaborate its application potential in the in situ marine oil spill bioremediation.

\section{Materials and methods}

\subsection{Chemicals and culture media}

The seawater used for media was obtained from Jiaozhou Bay, China. All chemicals, solvents and reagents used in the present study were of analytical grade. The diesel used in this experiment is 0 \# light diesel. The main media prepared for experiments are shown in Table 1.

\subsection{Experimental methods}

\subsubsection{Isolation and identification of diesel-degrading bacteria}

The seawater sample $(5 \mathrm{~mL})$ collected from Jiaozhou Bay was added in $250-\mathrm{mL}$ Erlenmeyer flask containing $100 \mathrm{~mL}$ mineral medium with diesel oil concentration of $400 \mathrm{mg} / \mathrm{L}$. Then, the medium was incubated in $28{ }^{\circ} \mathrm{C}$ at $130 \mathrm{r} / \mathrm{min}$ for 5 days. The enrichment process was repeated with increasing diesel oil concentration to $600 \mathrm{mg} / \mathrm{L}$. After two transfers, serial dilutions of enrichment culture were inoculated on LB solid medium and incubated at $28^{\circ} \mathrm{C}$. After 3 days, colonies with different morphologies were selected and purified as diesel-degrading microorganisms. Isolated strain was preserved with $2216 \mathrm{E}$ solid medium and stored in refrigerator at $4{ }^{\circ} \mathrm{C}$ for further use.

\subsubsection{Biodegradation of diesel oil}

The degradability of diesel of all strains (MJ1-MJ12) was measured by ultraviolet spectrophotometry (Shi et al. 2019). Analysis of degradation products was conducted by gas chromatography and mass spectrometry (GC-MS, 7890/5975C, Agilent, USA) (Bezza and Chirwa 2015). A series of 250$\mathrm{mL}$ Erlenmeyer flasks were used for this experiment. The purified diesel-degrading bacterium was inoculated in LB liquid medium in $28^{\circ} \mathrm{C}$ at $130 \mathrm{r} / \mathrm{min}$ for $16 \mathrm{~h}$. Then, $4 \mathrm{~mL}$ 
Table 1 Culture media

\begin{tabular}{|c|c|c|}
\hline Medium name & Purpose & Formula \\
\hline Mineral medium & $\begin{array}{l}\text { The enrichment of microorganisms and degradation of diesel } \\
\text { oil }\end{array}$ & $\begin{array}{l}\mathrm{K}_{2} \mathrm{HPO}_{4} 1 \mathrm{~g} \\
\mathrm{NH}_{4} \mathrm{NO}_{3} 1 \mathrm{~g} \\
\text { Seawater with sterilization } 1 \mathrm{~L} \\
\text { pH: } 7.0-7.5\end{array}$ \\
\hline LB medium & Isolation of diesel-degrading bacteria & $\begin{array}{l}\text { Peptone } 10 \mathrm{~g} / \mathrm{L} \\
\text { Yeast extract } 5 \mathrm{~g} / \mathrm{L} \\
\mathrm{NaCl} 10 \mathrm{~g} / \mathrm{L} \\
\text { Agar powder }(10 \mathrm{~g}-15 \mathrm{~g}) / \mathrm{L} \\
\text { (solid medium) } \\
\text { pH: } 7.4\end{array}$ \\
\hline 2216E solid medium & The preservation of the isolate & $\begin{array}{l}\text { Peptone } 5 \mathrm{~g} \\
\text { Yeast extract } 1 \mathrm{~g} \\
\text { Agar powder } 15 \mathrm{~g} \\
\text { Seawater with sterilization } 1 \mathrm{~L} \\
\text { pH: } 7.0-7.5\end{array}$ \\
\hline
\end{tabular}

inoculum was prepared in $71 \mathrm{~mL}$ mineral medium with filtered diesel oil of $10 \mathrm{~g} / \mathrm{L}$ to determine the degrading ability of bacteria. Another same mineral medium was injected with $4 \mathrm{~mL} \mathrm{LB}$ liquid medium instead of the inoculum as the blank experiment. Mineral media for each strain were performed in triplicate and incubated in $28{ }^{\circ} \mathrm{C}$ at $130 \mathrm{r} / \mathrm{min}$ for 5 days.

\subsubsection{Analyses of 16S rRNA sequences}

GenElute DNA extraction kit from Sigma and universal primers 27F (5'-AGAGTTTGATCCTGGCTCAG-3') and 1492R (5'-TACGGCTACCTTGTTACGACTT-3') were used for bacterial DNA extraction and amplification in this study, respectively. The composition of the reaction mixture and PCR conditions were the same as Zhang et al. (2016). The products of amplification were sequenced by Sangon Biotech (Shanghai) Co., Ltd. The 16S rRNA sequence was submitted to GenBank for the similarity search by BLAST using the national center for biotechnology information (NCBI) Web site. Phylogenetic tree was generated from alignments by the neighbor-joining method, and the reliability of inferred tree was checked with bootstrap test using the MEGA7.0 program.

\subsubsection{Box-Behnken design for RSM}

The Box-Behnken design for RSM was employed using Design-Expert Software Version 9. Single-factor experiments were carried out to determine the influence of several environmental factors on diesel degradation for MJ4 before determination of the factors level in response surface methodology, such as temperature, $\mathrm{pH}$, diesel concentration, $P / N$ ratio and dosage quantity of $\mathrm{N}$ and $\mathrm{P}$. Experimental design is listed in Table 2. For each run, $4 \mathrm{~mL}$ culture suspension of MJ4 incubated in LB medium for $24 \mathrm{~h}$ was inoculated into $71 \mathrm{~mL}$ mineral medium in 100-mL Erlenmeyer flask with shaker rotary speed of $130 \mathrm{rpm}$ for 5 days.

Based on the results of single-factor experiments, we conducted an analysis of variance for selecting the factors used in response surface methodology. The results indicated that $\mathrm{pH}$, temperature and $P / N$ ratio were the most significant factors. The factors and levels of Box-Behnken experimental design for diesel degradation by MJ4 are shown in Table 3. The central composite design Box-Behnken was adopted to conduct 17 runs (five central points), while the three variables were selected as variable $A, B$ and $C$, respectively. The degrading rate of diesel by MJ4 for 5 days was specified as response value $Y$.

\section{Results and discussion}

\subsection{Isolation and identification of diesel-degrading bacteria}

Twelve diesel-degrading strains which were named MJ1 to MJ12 were isolated from the petroleum-contaminated seawater in Jiaozhou Bay, China. The colonial morphology of 12 strains is shown in Fig. 1. Degradation ability of the 12 strains on commercial diesel fuel at the concentration of $10 \mathrm{~g} / \mathrm{L}$ in the mineral medium was examined. As shown in Fig. 2, all strains are able to grow and degrade diesel oil with the efficiency of diesel oil degradation between $4.77 \%$ and $26.54 \%$ after 5 -day incubation. Among the 12 strains, strain MJ4 showed the highest degrading ability, which was further utilized in this study. 
Table 2 Design of single-factor experiments

\begin{tabular}{|c|c|c|c|c|c|c|}
\hline Runs & Variable & & $\mathrm{pH}$ & $\begin{array}{l}\text { Diesel concentra- } \\
\text { tion, } \mathrm{mg} / \mathrm{L}\end{array}$ & $P / N(N=0.35 \mathrm{~g} / \mathrm{L})$ & Temp \\
\hline 1 & Temp & 16 & 7 & 10 & $1: 2$ & - \\
\hline 2 & & 20 & & & & \\
\hline 3 & & 24 & & & & \\
\hline 4 & & 28 & & & & \\
\hline 5 & & 32 & & & & \\
\hline 6 & $\mathrm{pH}$ & 5.4 & - & 10 & $1: 2$ & 28 \\
\hline 7 & & 6.2 & & & & \\
\hline 8 & & 7.0 & & & & \\
\hline 9 & & 8.8 & & & & \\
\hline 10 & & 9.5 & & & & \\
\hline 11 & Diesel concentration, mg/L & 5 & 7 & - & $1: 2$ & 28 \\
\hline 12 & & 10 & & & & \\
\hline 13 & & 15 & & & & \\
\hline 14 & & 20 & & & & \\
\hline 15 & & 25 & & & & \\
\hline 16 & $\mathrm{~K}_{2} \mathrm{HPO}_{3} / \mathrm{NH}_{4} \mathrm{O}_{3}\left(w / w, \mathrm{NH}_{4} \mathrm{NO}_{3}=1 \mathrm{~g} / \mathrm{L}\right)$ & $4 / 3$ & 7 & 10 & - & 28 \\
\hline 17 & & 1 & & & & \\
\hline 18 & & $2 / 3$ & & & & \\
\hline 19 & & $1 / 3$ & & & & \\
\hline 20 & & 0 & & & & \\
\hline 21 & Dosage of $N$ and $P(A: N=0.35 \mathrm{~g} / \mathrm{L} ; P=0.178 \mathrm{~g} / \mathrm{L})$ & $A$ & 7 & 10 & - & 28 \\
\hline 22 & & $3 A / 4$ & & & & \\
\hline 23 & & $A / 2$ & & & & \\
\hline 24 & & $A / 4$ & & & & \\
\hline 25 & & 0 & & & & \\
\hline
\end{tabular}

Table 3 Factors and levels of Box-Behnken experimental design for diesel degradation by MJ4

\begin{tabular}{lllll}
\hline Factor & & \multicolumn{2}{l}{ Level } \\
\cline { 3 - 5 } & & -1 & 0 & 1 \\
\hline$A$ & $\mathrm{pH}$ & 8.1 & 8.8 & 9.5 \\
$B$ & Temperature & 24 & 28 & 32 \\
$C$ & $P / N$ ratio & $1 / 3$ & $2 / 3$ & 1 \\
\hline
\end{tabular}

The 16S rRNA gene sequence (1377 bp) of MJ4 was determined and compared with the previously recorded sequences by BLAST using NCBI Web site. According to the result of Blast search, the $16 \mathrm{~S}$ rRNA sequence of the MJ4 showed $99 \%$ similarity to the $16 \mathrm{~S}$ rRNA sequence of Bacillus megaterium strain GC61 (KF158230). Results of phylogenetic analysis suggested that the isolate belonged to the genus Bacillus and was named Bacillus megaterium MJ4. The phylogenetic tree of strain MJ4 is shown in Fig. 3.

\subsection{Effect of operating conditions on diesel oil degradation}

In order to obtain the optimum conditions for biodegradation of diesel oil with the newly isolated B. megaterium MJ4, further biodegradation experiments were carried out in 100$\mathrm{mL}$ Erlenmeyer flasks with temperature range of $16-32{ }^{\circ} \mathrm{C}$, or at $\mathrm{pH}$ range of 6.25-9.5, or with initial diesel oil concentration of 5-25 g/L, or with different $\mathrm{K}_{2} \mathrm{HPO}_{4} / \mathrm{NH}_{4} \mathrm{NO}_{3}$ ratio of $0-4: 3$, and different dosage of $N$ and $P$. As shown in Fig. 4a, the degrading rate of diesel oil increased from $2 \%$ to $14.94 \%$ with the increasing temperature ranged from $16{ }^{\circ} \mathrm{C}$ to $28^{\circ} \mathrm{C}$. However, it decreased when temperature is higher than $28^{\circ} \mathrm{C}$. This indicates that keeping appropriate temperatures for $B$. megaterium $\mathrm{MJ} 4$ is an effective method to enhance petroleum hydrocarbon degradation in the ocean. A dramatic change in diesel degradation is observed in Fig. 4b. The degradation rate of diesel increased rapidly from $8 \%$ to $55 \%$ by increasing $\mathrm{pH}$ from 6 to 8.8 . However, the degradation rate did not keep increasing after $\mathrm{pH}$ of 8.8 . This indicates that $B$. megaterium MJ4 is sensitive to $\mathrm{pH}$ variation. It was observed that degradation of diesel increased when 


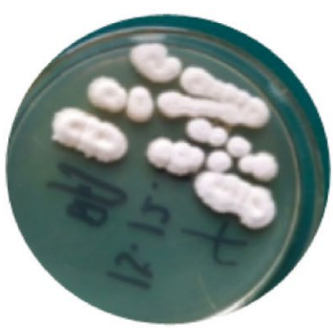

MJ1
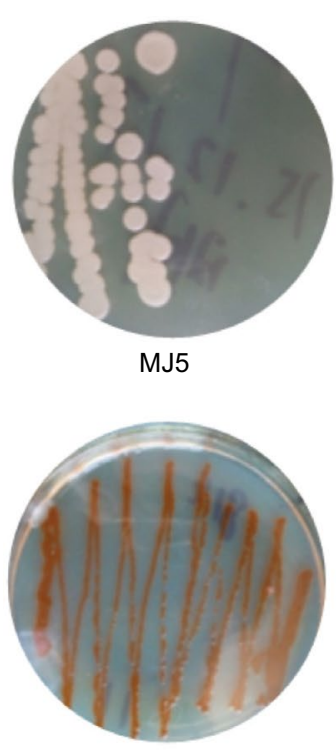

MJ9

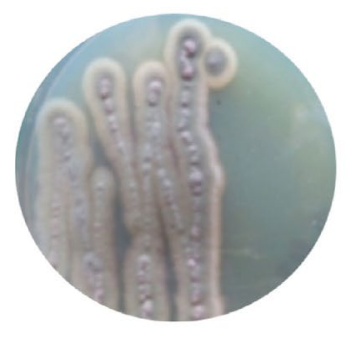

MJ2
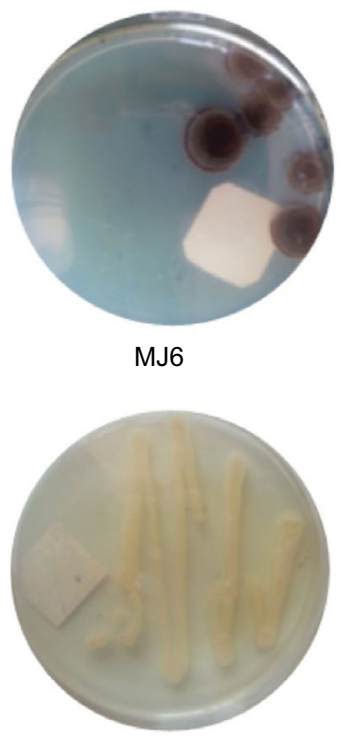

MJ10

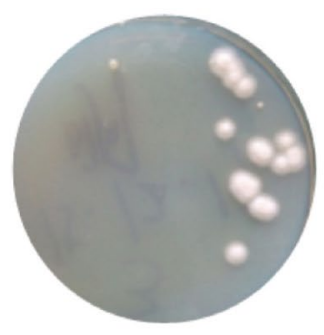

MJ3
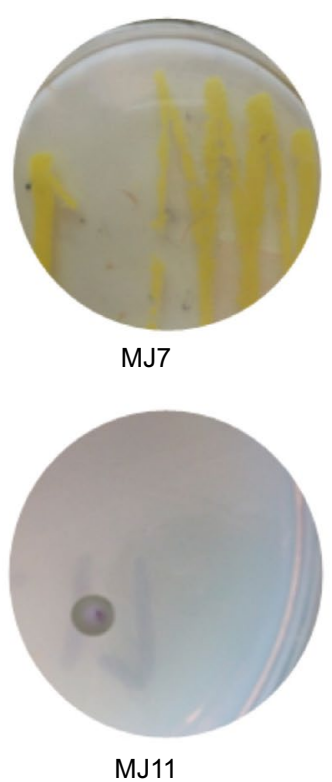
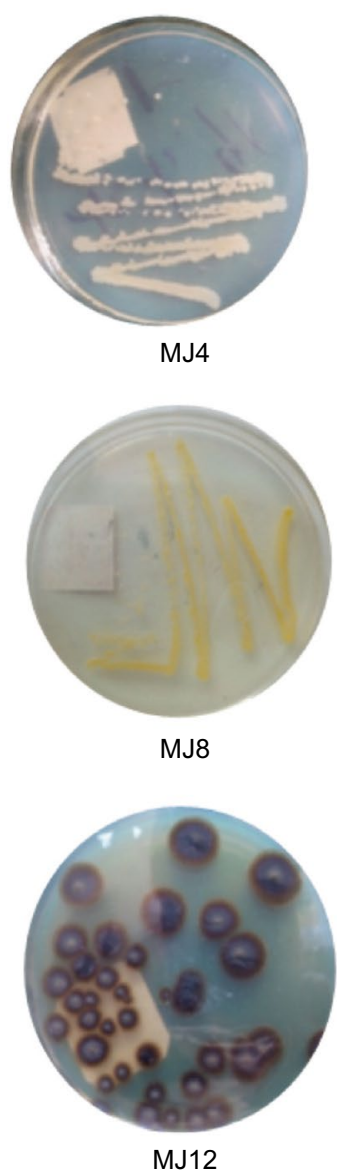

Fig. 1 Colonial morphology of the isolated diesel oil-degrading bacteria

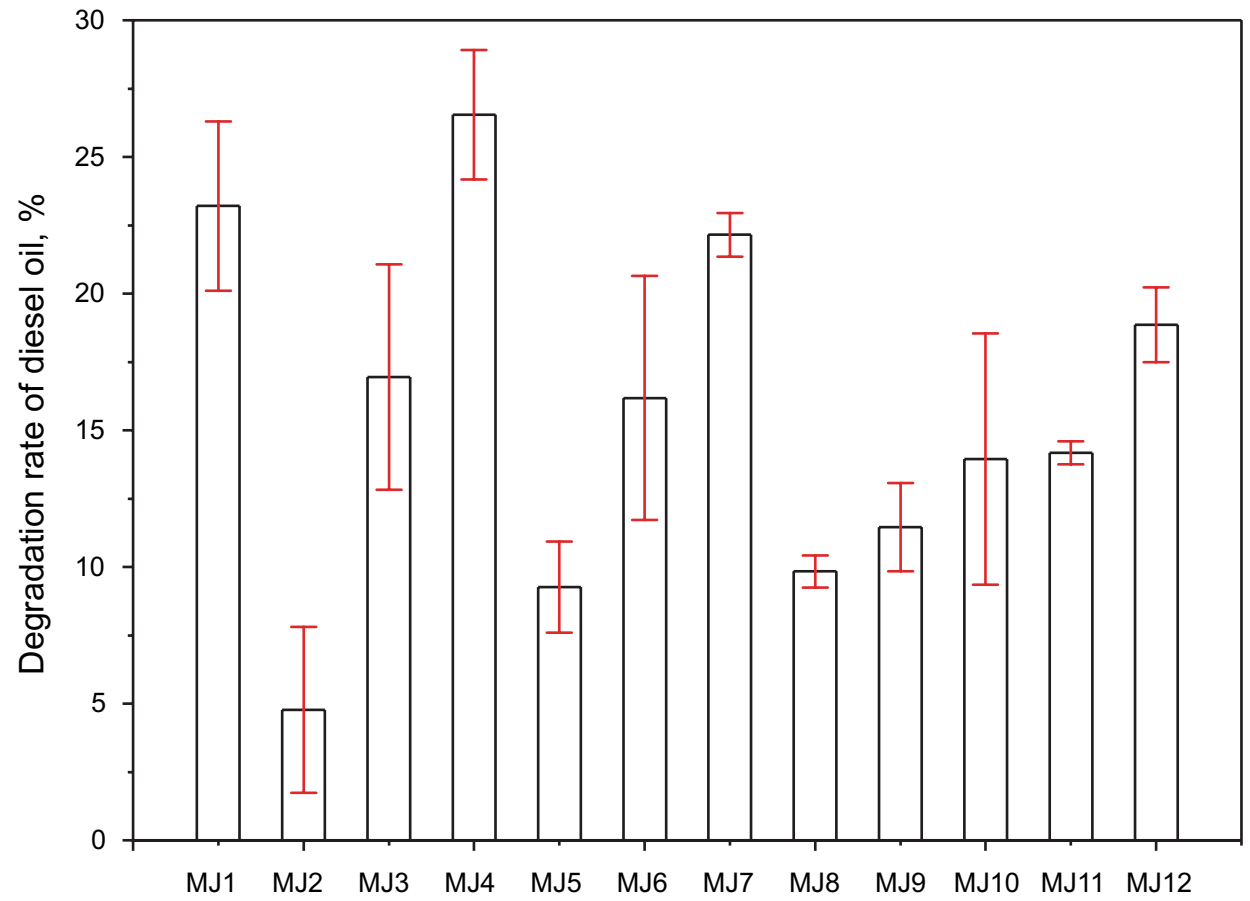

Fig. 2 Degrading rate of diesel oil for MJ1 to MJ12 


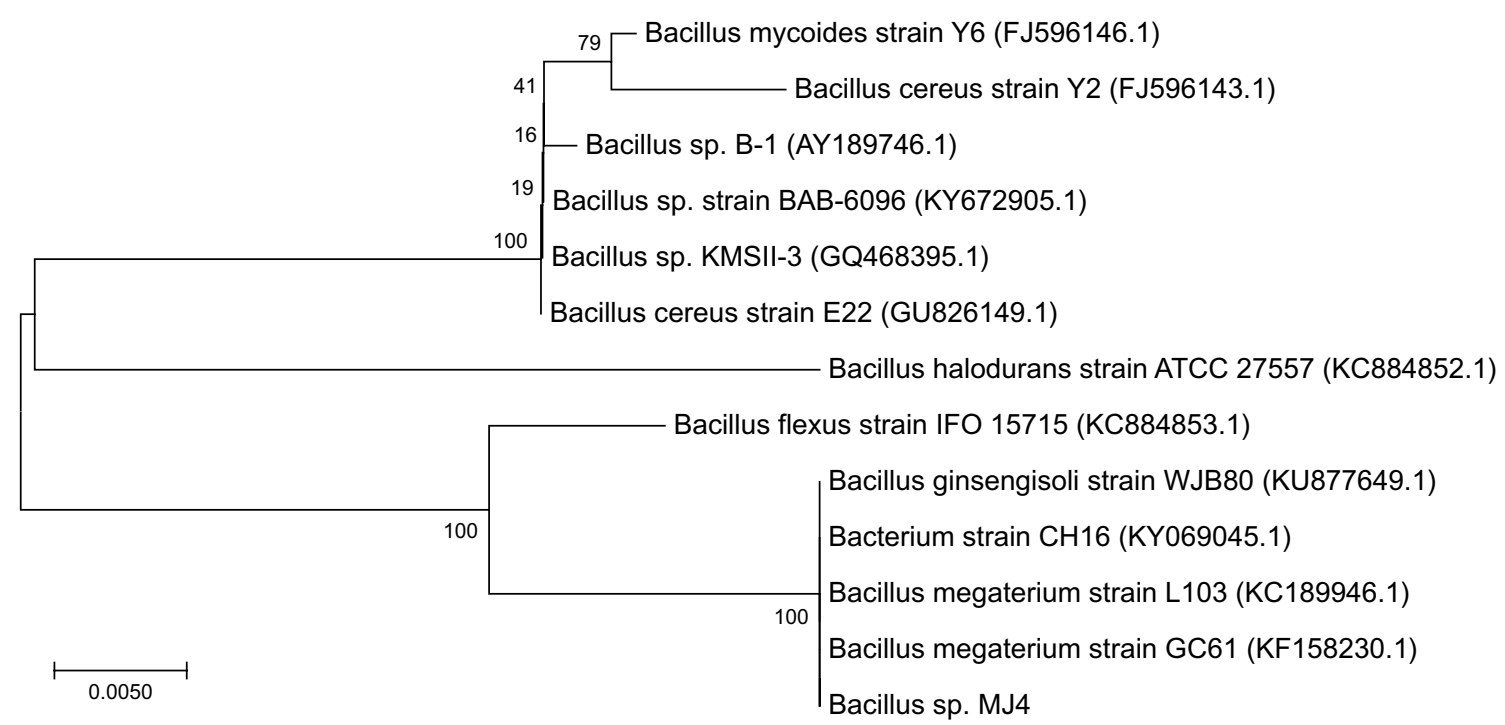

Fig. 3 Phylogenetic position of strain MJ4 within the genus Bacillus and allied bacteria. The branching pattern was generated by the neighborjoining method. The number of each branch indicates the bootstrap values

heightening the initial concentration of diesel within certain range (up to $25 \mathrm{~g} / \mathrm{L}$ ) in Fig. 4c. According to Fig. 4d, the degrading rate of diesel has a tendency of increasing when the addition of phosphorus increases. The highest degrading rate is $17.31 \%$ when the $\mathrm{K}_{2} \mathrm{HPO}_{3} / \mathrm{NH}_{4} \mathrm{NO}_{3}$ ratio $(w / w)$ is $4: 3$. For the degradation of diesel oil with strain MJ4, the results revealed that the optimum temperature (Fig. 4a) was observed at $28{ }^{\circ} \mathrm{C}$, the optimum pH (Fig. 4b) was 8.8, with high tolerance up to $25 \mathrm{~g} / \mathrm{L}$ to high diesel oil-contaminated water (Fig. 4c), and less tolerance to reduction of nitrogen and phosphorus (Fig. 4d, e).

However, considering the reduction in $\mathrm{K}_{2} \mathrm{HPO}_{4} / \mathrm{NH}_{4} \mathrm{NO}_{3}$ ratio means saving treatment cost and minimizing the risk to form water eutrophication, $\mathrm{K}_{2} \mathrm{HPO}_{4} / \mathrm{NH}_{4} \mathrm{NO}_{3}$ ratio of $2: 3$ with the diesel oil degradation efficiency of $15.51 \%$ was selected as the optimum $\mathrm{K}_{2} \mathrm{HPO}_{4} / \mathrm{NH}_{4} \mathrm{NO}_{3}$ ratio for subsequent experiments.

\subsection{Interaction among factors influencing diesel oil biodegradation}

The optimal combination of the three factors, namely temperature, $\mathrm{pH}$, and $P / N$ ratio, was determined by Box-Behnken design (BBD). The response values obtained by the experiment are reasonably consistent with those predicted by the Design-Expert software (Table 4), indicating that the key factors of the system can be described by a quadratic equation. A maximum diesel oil removal produced by the BBD design was further validated. A quadratic function formulation of the optimization process for the overall maximum biodegradation percentage $(Y)$ was obtained:

$$
\begin{aligned}
Y= & 70.32+2.96 A+0.46 B+13.83 C+6.92 A B+2.89 A C \\
& -4.02 B C-16.81 A^{2}-3.17 B^{2}-28.33 C^{2} .
\end{aligned}
$$

where $A$ is $\mathrm{pH}, B$ is temperature and $C$ is $P / N$ ratio. The positive signal corresponds to the synergistic effect in the degradation process, while the negative signal corresponds to the antagonistic effect. The 3D graphs reflect the interaction of the three factors with the response of the maximum biodegradation percentage of diesel oil (Fig. 5).

The ANOVA of regression equation results is presented in Table 5. According to Table 5, the model $F$ value of 44.07 and value of "Prob $>F$ " which is less than 0.0001 imply the model is significant.

Goodness of fit was examined by the determination coefficient $\left(R^{2}=0.9827\right)$, which suggests that more than $98.27 \%$ of variance can be explained by the model. The determination coefficient of the goodness of fit $\left(R^{2}=0.9827\right)$ indicated that more than $98.27 \%$ of variance can be explained by the

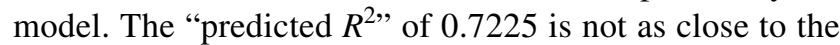

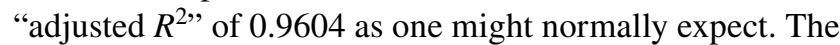
coefficient of variation $(\mathrm{CV}=8.71 \%)$ indicated that the experiments were precise and reliable.

Analysis of variance results of the second-order response surface model and the significance of each coefficient are given in Tables 5 and 6, respectively. According to Table 6, $P / N$ ratio shows a significant linear main effect $(P<0.0001)$, while $\mathrm{pH}(A)$ and temperature $(B)$ are not significant among the three factors; the interaction between $\mathrm{pH}(A)$ and temperature $(B)$ is significant, while the interactions among $\mathrm{pH}$ $(A)$ and $P / N$ ratio, temperature $(B)$ and $P / N$ ratio $(C)$ are not significant; in the twice terms, only temperature $\left(B^{2}\right)$ is not significant. 

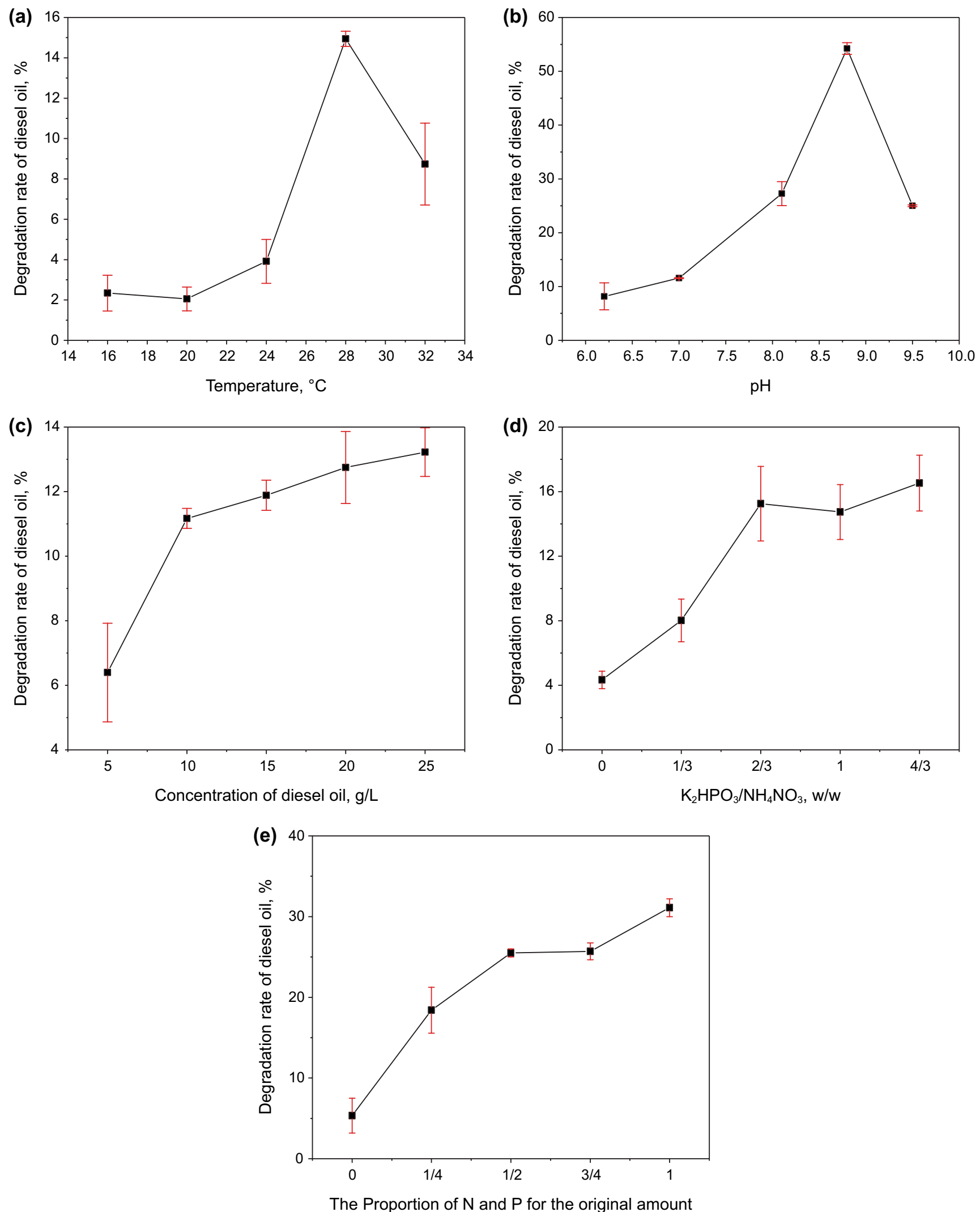

Fig. 4 Effect of temperature (a), $\mathrm{pH}(\mathbf{b})$, diesel oil concentration (c), phosphorus-to-nitrogen ratio (d) and dosage of phosphorus and nitrogen (e) on diesel removal by Bacillus sp. MJ4 
Table 4 Box-Behnken experimental results of diesel oil degradation by MJ4

\begin{tabular}{lrrrll}
\hline Standard order & $A$ & $B$ & $C$ & Actual value, $\%$ & $\begin{array}{l}\text { Predicted } \\
\text { value, } \%\end{array}$ \\
\hline 1 & -1 & -1 & 0 & 55.00 & 53.84 \\
2 & 1 & 0 & 1 & 46.01 & 44.86 \\
3 & 0 & 1 & -1 & 28.83 & 29.47 \\
4 & 0 & 1 & 1 & 50.53 & 49.09 \\
5 & -1 & 0 & -1 & 12.31 & 11.28 \\
6 & 0 & -1 & 1 & 52.52 & 56.21 \\
7 & -1 & 1 & 0 & 40.07 & 40.92 \\
8 & 1 & 0 & -1 & 13.83 & 11.42 \\
9 & -1 & 0 & 1 & 32.33 & 33.16 \\
10 & 0 & 0 & 0 & 70.32 & 70.32 \\
11 & 0 & 0 & 0 & 70.32 & 70.32 \\
12 & 1 & -1 & 0 & 44.27 & 45.92 \\
13 & 0 & 0 & 0 & 70.32 & 70.32 \\
14 & 0 & 0 & 0 & 70.32 & 70.32 \\
15 & 1 & 1 & 0 & 58.32 & 60.68 \\
16 & 0 & -1 & -1 & 21.32 & 20.51 \\
17 & 0 & 0 & 0 & 70.32 & 70.32 \\
\hline
\end{tabular}

\subsection{Analysis of the interactive effect of factors on the response}

As shown in Fig. 5, the 2D contour map and 3D response surface are used to graph the regression equation. The model predicts the maximum diesel oil degradation rate is $72.21 \%$ under the condition of the temperature of $28^{\circ} \mathrm{C}, \mathrm{pH}$ of 8.88 and $P / N$ ratio of 0.31 . Subsequent experiments under the optimized conditions show the degradation rate is $70.62 \%$, which indicates the model is precise and reliable.

\subsection{Analysis of diesel degradation products}

The further degraded sample which was obtained under the optimized conditions by RSM method and nonbiological control samples were qualitatively analyzed by GC-MS and are compared in Fig. 6. The best structural match between the retained data and the mass spectrum interpretation is listed in Table 7. Figure $6 \mathrm{a}$ and $\mathrm{b}$ represents the gas chromatograms of nonbiological and biodegradable diesel samples, respectively. It was observed that almost all the peaks disappeared in the biological sample inoculated with strain MJ4, (Fig. 6b). Compared with nonbiodiesel samples, the concentration of diesel oil in the samples added with petroleum-degrading bacteria MJ4 was significantly reduced. According to the gas chromatographic analysis in Fig. 6, the inoculated MJ4 degraded almost all the normal alkanes (C10-C20) in diesel within 5 days. The degradation rate of compounds in the range of
C12-C20 can reach more than $80 \%$ (Table 7). The analysis of crude oil degradation products by Punniyakotti et al. showed that Bacillus subtilis A1 has high degradation ability for petroleum hydrocarbons of different chain lengths (Punniyakotti et al. 2017).

\section{Discussion}

Bioavailability of nutrients, such as nitrogen and phosphorus, and environmental factors, such as temperature and ecological interactions, often limit the degradation rate of petroleum hydrocarbons in the marine environment (Ali Khan et al. 2017). Firstly, the different nutrients, environmental factors stimulate different taxa of oil-degrading bacteria. Bargiela et al. (2015) found that low temperature can improve the richness of bacteria and reduce the diversity of metabolism. Secondly, the enzymatic activity of microorganisms is largely restrained under the condition of temperature, $\mathrm{pH}$, even nutrient. $\mathrm{pH}$ of seawater is typically limited to a range between 7.5 and 8.4. The main reason for long-term changes in ocean $\mathrm{pH}$ is anthropogenic carbon dioxide emissions. However, other factors, such as watershed processes, nutrient inputs, changes in ecosystem structure and metabolism, can also affect $\mathrm{pH}$ changes in coastal ecosystems (Duarte et al. 2013). In the process of petroleum degradation, the catalytic action of enzymes such as paraffin monooxygenase, fatty alcohol dehydrogenase and fatty aldehyde dehydrogenase is also very important. In addition, the production of biosurfactants during diesel degradation is also affected by environmental factors, such as temperature and $\mathrm{pH}$ value ( $\mathrm{Li}$ et al. 2015). A large amount of emplastic was discovered among the bacterial colonies, and the amount increased with increasing temperature in the cultivation of crude oil-degrading strain (Liu et al. 2016). During the degradation process of crude oil-degrading bacteria, a large amount of viscous substances appeared in the colony, and the amount increased with the increase in temperature (Liu et al. 2016). In diesel-water system with $50 \mathrm{mg} / \mathrm{L}$ of rhamnolipid, the optimal $\mathrm{pH}$ value for microbial growth and diesel biodegradation was 7.2; when the $\mathrm{pH}$ value was lower than 5.2 or higher than 8.4 , the diesel degradation rate was significantly reduced (Whang et al. 2009). For the bacterium isolated in this study, it might be that the enzymes of microorganisms lost activity under the acidic or excessive basic conditions. In order to enhance the degradation of diesel oil, supplement of alkalinity should be considered in the bioremediation of diesel contamination with Bacillus sp. MJ4.

According to the results, the biodegradation ratio of diesel by MJ4 increases steadily with the increased diesel concentration, which indicates that the bacterium could be applied in bioremediation of high-concentration diesel leakage. Since oxygenases are involved in the major degradation 

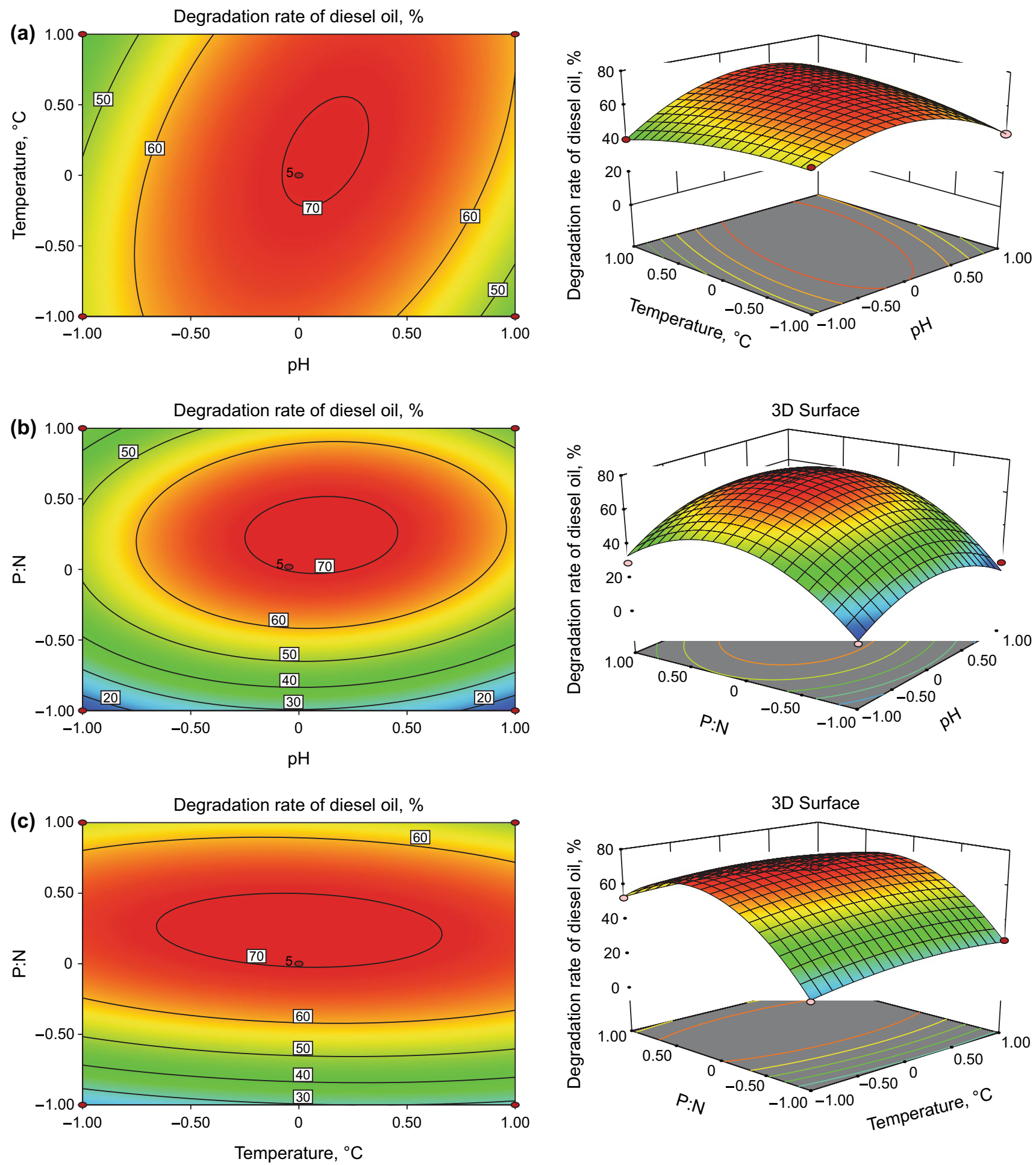

Fig. 5 2D contour plot and 3D response surface plot of biodegradation removal (\%) under reciprocal effect of a temperature and $\mathrm{pH}, \mathbf{b} P / N$ ratio and $\mathrm{pH}$ and $\mathrm{c} P / N$ ratio and temperature

pathways of both saturated and aromatic hydrocarbons, it is generally believed that petroleum hydrocarbons can only be extensively degraded in the environment under aerobic conditions (Fritsche and Hofrichter 2008; Xue et al. 2019).
Therefore, if the initial concentration of diesel oil is high to cover the surface of the ocean, the bioremediation is dangerous to complete. 
Table 5 ANOVA for the quadratic model

\begin{tabular}{llllll}
\hline & Square & Degree of freedom & Mean square & $F$ value & $\begin{array}{l}p \text { value } \\
\text { Prob }>F\end{array}$ \\
\hline Model & 6820.51 & 9 & 757.83 & 44.07 & $<0.0001$ \\
Residual & 120.38 & 7 & 17.20 & & Significant \\
Lack of fit & 120.38 & 3 & 40.13 & \\
Pure error & 0.000 & 4 & 0.000 & & \\
Cor total & 6940.90 & 16 & & Predicted $R^{2}=0.7225$ \\
$R^{2}=0.9827$ & Adjusted $R^{2}=0.9604$ & & & \\
\hline
\end{tabular}

Nutrients (such as nitrogen and phosphorus) are the limiting factors to improve the biodegradation rate of hydrocarbons in marine environment (Hazen et al. 2016; Wang et al. 2016). Fertilizers containing bioavailable nitrogen and phosphorus have been successfully used to enhance the biodegradation of petroleum in many regions, including the arctic (Atlas and Bragg 2009; Swannell et al. 1999).
According to the results of nutrient addition in this study, the degrading rate of diesel has a tendency of increasing when the addition of phosphorus and nitrogen increases. Effect of fertilizer on biodegradation of crude oil by marine isolates of B. megaterium $\mathrm{MJ} 4$ showed that the optimal phosphorusto-nitrogen ratio was 0.38 , which is a little different with present experiment (the optimal $P / N$ ratio in the present study

Table 6 Analysis of variance table

\begin{tabular}{|c|c|c|c|c|c|c|}
\hline \multirow[t]{2}{*}{ Factor } & \multirow[t]{2}{*}{ Coefficient estimate } & \multirow[t]{2}{*}{ Degree of freedom } & \multirow[t]{2}{*}{ Standard error } & \multicolumn{2}{|l|}{$95 \% \mathrm{CI}$} & \multirow[t]{2}{*}{$P$ value } \\
\hline & & & & Low & High & \\
\hline Intercept & 70.32 & 1 & 1.85 & 65.94 & 74.71 & \\
\hline$A$ & 2.96 & 1 & 1.47 & -0.51 & 6.43 & 0.0833 \\
\hline$B$ & 0.46 & 1 & 1.47 & -3.01 & 3.93 & 0.7631 \\
\hline$C$ & 13.83 & 1 & 1.47 & 10.36 & 17.29 & $<0.0001$ \\
\hline$A B$ & 6.92 & 1 & 2.07 & 2.02 & 11.83 & 0.0124 \\
\hline$A C$ & 2.89 & 1 & 2.07 & -2.01 & 7.79 & 0.2063 \\
\hline$B C$ & -4.02 & 1 & 2.07 & -8.93 & 0.88 & 0.0936 \\
\hline$A^{2}$ & -16.81 & 1 & 2.02 & -21.59 & -12.03 & $<0.0001$ \\
\hline$B^{2}$ & -3.17 & 1 & 2.02 & -7.95 & 1.61 & 0.1609 \\
\hline$C^{2}$ & -28.33 & 1 & 2.02 & -33.11 & -23.55 & $<0.0001$ \\
\hline
\end{tabular}
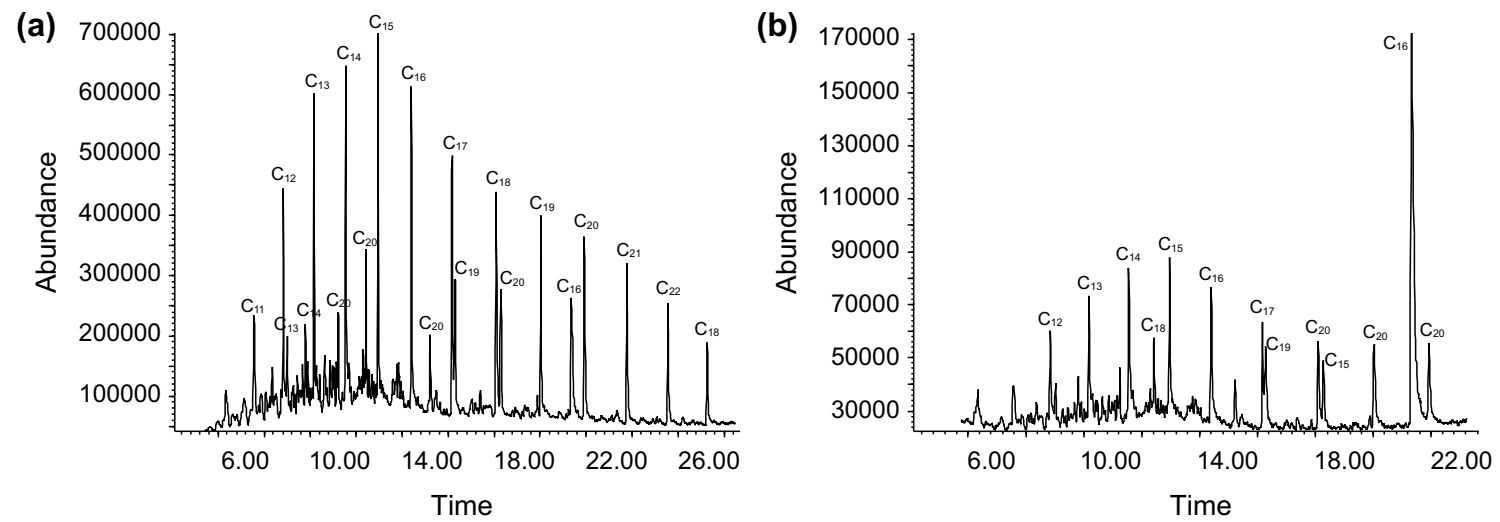

Fig. 6 Gas chromatography and mass spectrometry (GC-MS) characterize the residual diesel in diesel degradation. a Nonbiological control system; b Strain MJ4 
Table 7 Determination of the composition and degradation rate of residual diesel oil by GC-MS

\begin{tabular}{|c|c|c|c|c|c|}
\hline$R T$ & Compounds & Chemical formula & $M W$ & MD & BE, $\%$ \\
\hline 8.843 & Dodecane & $\mathrm{C}_{12} \mathrm{H}_{26}$ & 170 & 93 & 87 \\
\hline 10.18 & Tridecane & $\mathrm{C}_{13} \mathrm{H}_{28}$ & 184 & 97 & 81 \\
\hline 11.559 & Tetradecane & $\mathrm{C}_{14} \mathrm{H}_{30}$ & 198 & 98 & 86 \\
\hline 12.429 & Octadecane & $\mathrm{C}_{18} \mathrm{H}_{38}$ & 254 & 70 & 92 \\
\hline 12.947 & Pentadecane & $\mathrm{C}_{15} \mathrm{H}_{32}$ & 212 & 96 & 75 \\
\hline 14.398 & Hexadecane & $\mathrm{C}_{16} \mathrm{H}_{34}$ & 226 & 98 & 78 \\
\hline 16.18 & Heptadecane & $\mathrm{C}_{17} \mathrm{H}_{36}$ & 240 & 98 & 99 \\
\hline 16.284 & Heptadecane, 2,6-dimethyl- & $\mathrm{C}_{19} \mathrm{H}_{40}$ & 268 & 92 & 96 \\
\hline 18.098 & Eicosane & $\mathrm{C}_{20} \mathrm{H}_{42}$ & 282 & 97 & 90 \\
\hline 18.284 & Dodecane, 2,6,11-trimethyl- & $\mathrm{C}_{15} \mathrm{H}_{32}$ & 212 & 86 & 73 \\
\hline 20.035 & Eicosane & $\mathrm{C}_{20} \mathrm{H}_{42}$ & 282 & 96 & 87 \\
\hline 21.341 & Dibutyl phthalate & $\mathrm{C}_{16} \mathrm{H}_{22} \mathrm{O}_{4}$ & 278 & 96 & 76 \\
\hline 21.922 & Eicosane & $\mathrm{C}_{20} \mathrm{H}_{42}$ & 282 & 95 & 91 \\
\hline
\end{tabular}

$R T$ retention time, $M W$ molecular weight

is 0.56) (Thavasi et al. 2011). Huang et al. (Huang et al. 2008) have optimized nitrogen and phosphorus addition in diesel oil degradation by Rhodococcus erythropolis which was isolated in oil-polluted seabed. The results indicated the optimal nitrogen and phosphorus addition is $0.46 \mathrm{~g} / \mathrm{L}$ and $0.6 \mathrm{~g} / \mathrm{L}$, respectively. Generally, the addition of nitrogen and phosphorus will facilitate the growth of the microorganisms, thereby improving degradation of oil by microorganisms. Addition dosage of nitrogen and phosphorus on biodegradation of crude oil by marine isolates of Bacillus megaterium showed that the optimal phosphorus dosage and nitrogen dosage are $0.23 \mathrm{~g} / \mathrm{L}$ and $0.089 \mathrm{~g} / \mathrm{L}$, respectively, and there was no significant change observed in bacterial cell growth and biodegradation rate beyond the optimal dosage (Thavasi et al. 2011). The difference between two results should be attributed as the different nitrogen sources were used; in the present study, $\mathrm{NH}_{4} \mathrm{NO}_{3}$ was used and it can emulsify diesel.

\section{Conclusions}

The present study demonstrated the isolation and identification of a novel indigenous petroleum-degrading bacterial strains from the oily seawater of Jiaozhou Bay. Single-factor experiments and RSM-BBD were used to evaluate and optimize the environmental factors for affecting the diesel oil degradation process of $B$. megaterium MJ4. A nonlinear regression equation of diesel oil degradation rate and $\mathrm{pH}$, temperature, $P / N$ ratio was obtained. Experiments under the optimized conditions show the degradation rate is $70.62 \%$, which indicates the model is precise and reliable. Analysis of diesel degradation products by GC-MS shows that $B$. megaterium MJ4 can degrade alkane components in various ranges, proving that MJ4 is a very effective crude oildegrading bacterium. In conclusion, B. megaterium MJ4 could be utilized to enhance the biodegradation of complex hydrocarbon components, including marine oil spills, due to their low cost and environmental friendliness. In the future, the growth of MJ4 during oil spill remediation and its impact on other indigenous marine microorganism will be studied.

Acknowledgements This work was supported by the Scientific Research Foundation of Shandong University of Science and Technology under Grant for Recruited Talents [2014RCJJ015], Project of Shandong Province Higher Educational Young Innovative Talent Introduction and Cultivation Team [Hydrogen energy chemistry innovation team] and the Science and Technology Projects of Qingdao (Grant No. 19-6-2-25-cg).

Open Access This article is licensed under a Creative Commons Attribution 4.0 International License, which permits use, sharing, adaptation, distribution and reproduction in any medium or format, as long as you give appropriate credit to the original author(s) and the source, provide a link to the Creative Commons licence, and indicate if changes were made. The images or other third party material in this article are included in the article's Creative Commons licence, unless indicated otherwise in a credit line to the material. If material is not included in the article's Creative Commons licence and your intended use is not permitted by statutory regulation or exceeds the permitted use, you will need to obtain permission directly from the copyright holder. To view a copy of this licence, visit http://creativecommons.org/licenses/by/4.0/.

\section{References}

Adam G, Duncan HJ. Effect of diesel fuel on growth of selected plant species. Environ Geochem Health. 1999;21(4):353-7. https://doi. org/10.1023/A:1006744603461 
Ali Khan AH, Tanveer S, Alia S, Anees M, Sultan A, Iqbal M, et al. Role of nutrients in bacterial biosurfactant production and effect of biosurfactant production on petroleum hydrocarbon biodegradation. Ecol Eng. 2017;104:158-64. https://doi.org/10.1016/j. ecoleng.2017.04.023.

Atlas R, Bragg J. Bioremediation of marine oil spills: when and when not - the Exxon Valdez experience. Microb Biotechnol. 2009;2:213-21. https://doi.org/10.1111/j.1751-7915.2008.00079 .X.

Atlas RM, Hazen TC. Oil biodegradation and bioremediation: a tale of the two worst spills in U.S. history. Environ Sci Technol. 2011;45:6709-15. https://doi.org/10.1021/es2013227.

Bao MT, Wang LN, Sun PY, Cao LX, Zou J, Li YM. Biodegradation of crude oil using an efficient microbial consortium in a simulated marine environment. Mar Pollut Bull. 2012;64(6):1177-85. https ://doi.org/10.1016/j.marpolbul.2012.03.020.

Bargiela R, Mapelli F, Rojo D, Chouaia B, Tornés J, Borin S, et al. Bacterial population and biodegradation potential in chronically crude oil-contaminated marine sediments are strongly linked to temperature. Sci Rep. 2015;5:11651. https://doi.org/10.1038/srep1 1651.

Bento FM, Camargo FAC, Okeke BC, Frankenberger WT. Diversity of biosurfactant producing microorganisms isolated from soils contaminated with diesel oil. Microbiol Res. 2005;160(3):249-55. https://doi.org/10.1016/j.micres.2004.08.005.

Bezza FA, Chirwa EMN. Production and applications of lipopeptide biosurfactant for bioremediation and oil recovery by Bacillus subtilis CN2. Biochem Eng J. 2015;101:168. https://doi. org/10.1016/j.bej.2015.05.007.

Duarte CM, Hendriks IE, Moore TS, Olsen YS, Steckbauer A, Ramajo $\mathrm{L}$, et al. Is ocean acidification an open-ocean syndrome understanding anthropogenic impacts on seawater $\mathrm{pH}$. Estuaries Coasts. 2013;36:221-36. https://doi.org/10.1007/s12237-013-9594-3.

Fritsche W, Hofrichter M. Aerobic degradation by microorganisms. Biotechnology: environmental processes II, Second edition, vol. 11b. New York: Wiley-VCH; 2008. p. 144-67.

Gallego JLR, Loredo J, Llamas JF, Vázquez F, Sánchez J. Bioremediation of diesel-contaminated soils: evaluation of potential in situ techniques by study of bacterial degradation. Biodegradation. 2001;12:325-35. https://doi.org/10.1023/A:1014397732435.

Hallenbeck PC, Grogger M, Mraz M, Veverka D. The use of design of experiments and response surface methodology to optimize biomass and lipid production by the oleaginous marine green alga, Nannochloropsis gaditana in response to light intensity, inoculum size and $\mathrm{CO}_{2}$. Biores Technol. 2015;184:161-8. https://doi. org/10.1016/j.biortech.2014.09.022.

Hazen TC, Prince RC, Mahmoudi N. Marine oil biodegradation. Environ Sci Technol. 2016;50(5):2121-9. https://doi.org/10.1021/acs. est.5b03333.

Huang L, Ma T, Li D, Liang FL, Liu RL, Li GQ. Optimization of nutrient component for diesel oil degradation by Rhodococcus erythropolis. Mar Pollut Bull. 2008;56(10):1714-8. https://doi. org/10.1016/j.marpolbul.2008.07.007.

Karpagam R, Raj KJ, Ashokkumar B, Varalakshmi P. Characterization and fatty acid profiling in two fresh water microalgae for biodiesel production: lipid enhancement methods and media optimization using response surface methodology. Biores Technol. 2015;2015(188):177-84. https://doi.org/10.1016/j.biort ech.2015.01.053.

Kayode-Isola TM, Eniola KIT, Olayemi AB, Igunnugbemi OO. Response of resident bacteria of a crude oil-polluted river to diesel oil. Am-Eur J Agron. 2008;1(1):06-9.

Li SD, Pi YR, Bao MT, Zhang C, Zhao DW, Li YM, et al. Effect of rhamnolipid biosurfactant on solubilization of polycyclic aromatic hydrocarbons. Mar Pollut Bull. 2015;101(1):219-25. https://doi. org/10.1016/j.marpolbul.2015.09.059.
Liu BQ, Ju MT, Liu JP, Wu WT, Li XJ. Isolation, identification, and crude oil degradation characteristics of a high-temperature, hydrocarbon-degrading strain. Mar Pollut Bull. 2016;106:301-7. https ://doi.org/10.1016/j.marpolbul.2015.09.053.

Mahmoudi N, Porter TM, Zimmerman AR, Fulthorpe RR, Kasozi GN, Silliman BR, et al. Rapid degradation of deepwater horizon spilled oil by indigenous microbial communities in louisiana saltmarsh sediments. Environ Sci Technol. 2013;47(23):13303-12. https:// doi.org/10.1021/es4036072.

Michaud L, Lo Giudice A, Saitta M, De Domenico M, Bruni V. The biodegradation efficiency on diesel oil by two psychrotrophic Antarctic marine bacteria during a two-month-long experiment. Mar Pollut Bull. 2004;49:405-9. https://doi.org/10.1016/j.marpo lbul.2004.02.026

Mnif I, Mnif S, Sahnoun R, Maktouf S, Ayedi Y, Ellouze-Chaabouni $\mathrm{S}$, et al. Biodegradation of diesel oil by a novel microbial consortium: comparison between co-inoculation with biosurfactantproducing strain and exogenously added biosurfactants. Environ Sci Pollut Res. 2015;22(19):14852-61. https://doi.org/10.1007/ s11356-015-4488-5.

Pi Y, Meng L, Bao M, Sun P, Lu J. Degradation of crude oil and relationship with bacteria and enzymatic activities in laboratory testing. Int Biodeterior Biodegrad. 2016;106:106-16. https://doi. org/10.1016/j.ibiod.2015.10.015.

Punniyakotti P, Elumalai P, Machuca LL, Rahman P, Murugan K, Rajasekar A. Biosurfactant and degradative enzymes mediated crude oil degradation by bacterium Bacillus subtilis A1. Front Microbiol. 2017;8:193. https://doi.org/10.3389/fmicb.2017.00193

Rahman KSM, Rahman T, Lakshmanaperumalsamy P, Banat IM. Occurrence of crude oil degrading bacteria in gasoline and diesel station soils. J Basic Microbiol. 2002;42(4):284-91. https:// doi.org/10.1002/1521-4028(200208)42:4\%3c284::AID-JOBM2 84\%3e3.0.CO;2-M

Rajasekar A, Babu TG, Pandian STK, Maruthamuthu S, Palaniswamy N, Rajendran A. Role of Serratia marcescens ACE2 on diesel degradation and its influence on corrosion. J Ind Microbiol Biotechnol. 2007;34(9):589-98. https://doi.org/10.1007/s1029 5-007-0225-5.

Richard JY, Vogel TM. Characterization of a soil bacterial consortium capable of degrading diesel fuel. Int Biodeterior Biodegrad. 1999;44(2-3):93-100. https://doi.org/10.1016/S0964 -8305(99)00062-1.

Ron EZ, Rosenberg E. Enhanced bioremediation of oil spills in the sea. Curr Opin Biotechnol. 2014;27:191-4. https://doi.org/10.1016/j. copbio.2014.02.004.

Saadoun I. Isolation and characterization of bacteria from crude petroleum oil contaminated soil and their potential to degrade diesel fuel. J Basic Microbiol. 2002;42(6):420-8. https://doi. org/10.1002/1521-4028(200212)42:6\%3c420::AID-JOBM4 $20 \% 3 \mathrm{e} 3.0 . \mathrm{CO} ; 2-\mathrm{W}$.

Shi K, Xue JL, Xiao XF, Qiao YL, Wu YN, Gao Y. Mechanism of degrading petroleum hydrocarbons by compound marine petroleum-degrading bacteria: surface adsorption, cell uptake, and biodegradation. Energy Fuels. 2019;33:11373-9. https://doi. org/10.1021/acs.energyfuels.9b02306.

Swannell RPJ, Mitchell D, Lethbridge G, Jones D, Heath D, Hagley M, Jones M, Petch S, Milne R, Croxford R, Lee K. A field demonstration of the efficacy of bioremediation to treat oiled shorelines following the sea empress incident. Environ Technol. 1999;20(8):863-73. https://doi.org/10.1080/09593332008616881.

Thavasi R, Jayalakshmi S, Banat IM. Effect of biosurfactant and fertilizer on biodegradation of crude oil by marine isolates of Bacillus megaterium, Corynebacterium kutscheri and Pseudomonas aeruginosa. Biores Technol. 2011;102(2):772-8. https://doi. org/10.1016/j.biortech.2010.08.099. 
Wang X, Wang XJ, Liu M, Zhou LJ, Gu ZL, Zhao JF. Bioremediation of marine oil pollution by Brevundimonas diminuta: effect of salinity and nutrients. Desalin Water Treatment Sci Eng. 2016;57:19768-75. https://doi.org/10.1080/19443994.2015.11069 84.

Whang LM, Liu PWG, Ma CC, Cheng SS. Application of rhamnolipid and surfactin for enhanced diesel biodegradation-effects of $\mathrm{pH}$ and ammonium addition. J Hazard Mater. 2009;164(2-3):104550. https://doi.org/10.1016/j.jhazmat.2008.09.006.

Wu YN, Xu M, Xue JL, Shi K, Gu M. Characterization and enhanced degradation potentials of biosurfactant-producing bacteria isolated from a marine environment. ACS Omega. 2019;4:1645-51. https ://doi.org/10.1021/acsomega.8b02653.

Xu M, Fu XG, Gao Y, Duan LF, Xu CC, Sun WS, et al. Characterization of a biosurfactant-producing bacteria isolated from marine environment: surface activity, chemical characterization and biodegradation. J Environ Chem Eng. 2020;8:104277. https://doi. org/10.1016/j.jece.2020.104277.
Xue JL, Yu Y, Bai Y, Wang LP, Wu YN. Marine oil-degrading microorganisms and biodegradation process of petroleum hydrocarbon in marine environments: a review. Curr Microbiol. 2015;71:220-8. https://doi.org/10.1007/s00284-015-0825-7.

Xue JL, Wu YN, Shi K, Xiao XF, Gao Y, Li L, Qiao YL. Study on the degradation performance and kinetics of immobilized cells in straw-alginate beads in marine environment. Biores Technol. 2019;280:88-94. https://doi.org/10.1016/j.biortech.2019.02.019.

Xue JL, Shi K, Chen C, Bai Y, Cui QQ, Li NN, Fu XG, Qiao YL. Evaluation of response of dynamics change in bioaugmentation process in diesel-polluted seawater via high-throughput sequencing: Degradation characteristic, community structure, functional genes. J Hazard Mater. 2021;403:123569. https://doi. org/10.1016/j.jhazmat.2020.123569.

Zhang H, Tang J, Wang L, Liu J, Gurav RG, Sun K. A novel bioremediation strategy for petroleum hydrocarbon pollutants using salt tolerant Corynebacterium variabile HRJ4 and biochar. J Environ Sci. 2016;47:7-13. https://doi.org/10.1016/j.jes.2015.12.023. 